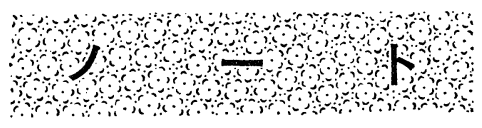

\title{
鶏胚を用いたテトロドトキシンの毒力検定試験法の検討
}

(昭和 50 年 12 月 19 日受理)

三浦 利 之* 粟飯 原 景 昭*

\section{Studies on the Toxicity Test of Tetrodotoxin by Chicken Embryos}

\section{Toshiyuki MiURA and Kageaki AIBARA}

(Department of Biomedical Research on Foods, National Institute of Health:

Kamiosaki, Shinagawa-ku, Tokyo)

This study aimed to establish a rapid and reliable biological test using chick embryos for estimation of toxicities of various substances contained in foods.

Tetrodotoxin was tested in this experiment. The sample dissolved in acetic acid solution, $\mathrm{pH} 3.5$ was inoculated into air cells or yolk sacs of White Leghorn fertile eggs aged three to seven days and toxicity of the sample was estimated by their mortalities during three days after inoculation. All the chick embryos proved more sensitive to air cell inoculation than yolk sac one, among which five day-old eggs were most sensitive.

Therefore, it is considered that the method with air cell inoculation using five dayold chick embryo is preferable concerning both sensitivity and reliabilty. Moreover, it was found that the chick embryo test was more excellent than the toxicity test using mouse because of its good sensitivity and reproducibility.

(Received December 19, 1975)

\section{緒言}

Platt ら¹)が1962年にアフラトキシンの毒力検定試験 法として，鶏胚を用いる方法を提案したのを契機とし て, 最近では多くのマイコトキシンのみならず諸化学物 質などの毒力検定試験法として鵎胚法が用いられてい

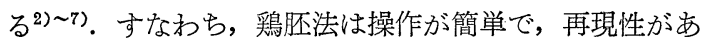
り，かつ鋭敏であるといら，いくつかの利点を有してい る.

そこで著者らは食品と関係をもつ, 多くの物質の安全 性を迅速に評価するための試験法を確立することを目的 として, 鷄胚を用いた生物学的試験法についての基礎的 研究を行ってきた。

今回はフグによる食中毒の原因物質として知られてい るテトロドトキシンについて，従来から行われているマ ウスによる毒力検定法と比較検討する目的で鷄胚法の応
用を試みた。

すなわち，マウスによる毒力検定法では用いるマウス の系統によってテトロドトキシンの毒性に対する感受性 が多少異なること, またこの種の実験動物の入手が困難 な地域もあるという，我が国の現状を考光，一般的に入 手が容易である有精鷄卵を用いた鵎胚法がテトロドトキ シンの毒力検定法に応用が可能か否かについて, 肧令お よび接種方法の面から検討した.

\section{実験方法}

\section{1. 試料およびその調製}

供試したテトロドトキシンは三共(株)製のもので, $\mathrm{pH} 3.5$ の酢酸溶液にて $0.1 \mu \mathrm{g} / \mathrm{ml}$ から $100 \mu \mathrm{g} / \mathrm{ml}$ の 各濃度の試料液を調製し：ミリポアフィルターを用いて 除菌処理操作を行った後, 実験に供した。

\section{2. 鷄胚法による毒性試験}

試験には採卵用白色レグホン種の有精卵を用いた。ふ 


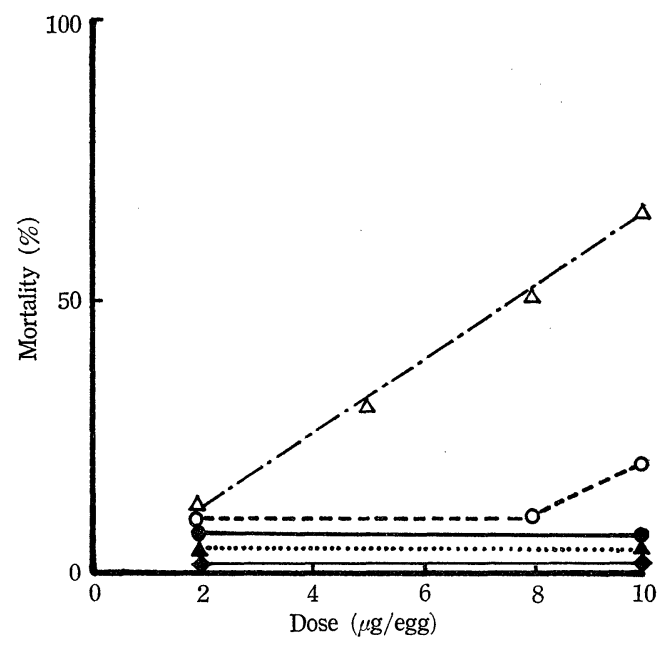

Fig. 1. Dose-response curves for the chicken embryos by the yolk sac inoculation of tetrodotoxin

$$
\triangle-\cdot-\triangle, 3 \text { day-old; } \bigcirc--\bigcirc, 4 \text { day-old; }
$$

$-\mathbf{0}, 5$ day-old; $\mathbf{\Delta} \cdots \mathbf{\Delta}, 6$ day-old;

- 7 day-old.

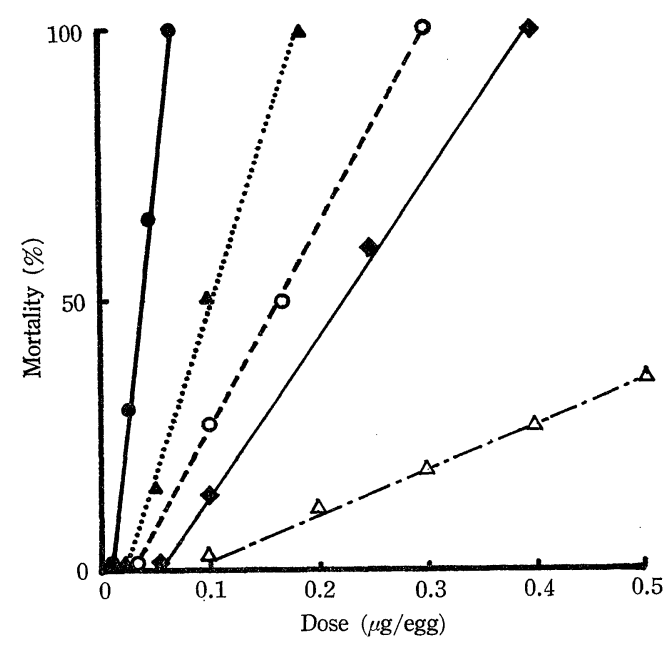

Fig. 2. Dose-response curves for the chicken embryos by the air cell inoculation of tetrodotoxin

$$
\begin{aligned}
& \triangle-\cdot-\triangle, 3 \text { day-old; } \bigcirc--\bigcirc, 4 \text { day-old; } \\
& -\mathbf{0}, 5 \text { day-old; } \mathbf{\Delta} \cdots \mathbf{\Delta}, 6 \text { day-old; } \\
& \longrightarrow 7 \text { day-old. }
\end{aligned}
$$

(卯) 卵開始後 3 日令から 7 日令の各肧令について気室内 (air cell 法) あるいは卵黄囊内（yolk sac 法）に試料 を接種 $(0.1 \mathrm{ml} / \mathrm{egg})$ する方法を用いた. な和試料接種 の手技は著者らが，すでに報告した方法7) に準じて行っ

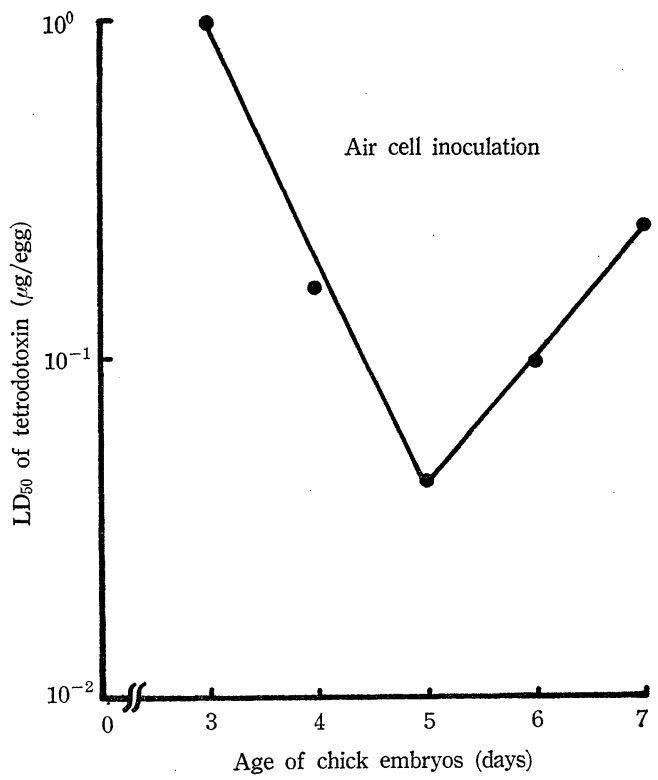

Fig. 3. Relations between $\mathrm{LD}_{50 \mathrm{~s}}$ of tetrodotoxin for the chick embryos and their ages

た.

実験結果は原則として，1試料 1 希釈段階について10 個の有精卵を使用し，4 回の反覆実験によった。ふ卯は 温度 $38^{\circ}$, 相対湿度 $60 \%$ の転卵装置つきふ卵器で行った。 接種後 $24 ， 48 ， 72$ 時間ごとに検卵し，最終的に72時間後 の鶏胚の生死を判定し, その憼死率をもって毒性の強さ とした

\section{実 験 結 果}

\section{1. 卵黄囊内接種}

畉黄袈内接種法ではいずれの胚令において子感度が低 く, 整死率は $10 \mu \mathrm{g} / 0.1 \mathrm{ml} / \mathrm{egg}$ の接種量で 3 日令の場 合 $65 \% ， 4$ 日令で10\%の值を示し，5 日令以上に拈いて は全く斃死するものが認められなかった (Fig. 1).

\section{2. 気室内接種}

気室内接種法においては，卵黄囊内接種の場合に比べ ると，はるかに感度は高い，乙かしながら，胚令と感度 が相関しないといら現象が認められた。すなわち，感度 は3 日令では低いが，4 日令，5 日令と肧令が進むに従 って急激に感度を増し 5 日令をピークとし, その後は漸 次低下することが分かった (Fig. 2).

Fig. 3 は毒性の強さと肧令との関係をより明らかに 示すため, Behrens 法によって求めた $\mathrm{LD}_{50}$ 值と胚令の 関係を示したものである.これからも $\mathrm{LD}_{50}$ 值は 5 日令 が最低となり，毒性に対する感度が最も高いことが分か る.

\section{考察}

鶏胚を用いテトロドトキシンの毒力検定を卵黄囊内接 
種および気室内接種の 2 方法によって検討したが，卵黄 囊内接種法では肧令とともに感度は低下する傾向を示 し, かつ検討した胚令中, 最も感度が高かった 3 日令と い党どもマウス法に比べて $1 / 50$ 以下と感度が極めて低い ことから，その応用は困難であることが認められた．

小倉 ${ }^{9)}$ はテトロドトキシンの吸収毒性は必ずしも急激 に現れず摄取後 $20 \sim 30$ 分ごろより作用が発現し, 現在の ところ酵素による毒素の分解反匛は見いだされていない が, 臓器成分, 温度, $\mathrm{pH}$ などの影響を受けやすく, 比 較的容易に毒性は低下すると述べ，さらに総説 ${ }^{10)}$ そ扔い てテトロドトキシンは $\mathrm{Na}^{+}, \mathrm{K}^{+}$の細胞膜透過性に対し て生理学的な効果をるっていると説明している.

卵黄囊内の成分 (タンパク質, 脂質, 炭水化物, ビタ ミン, 無機イオン, 酵素) の变化は一般的に肧の発育過 程の中期以降にみられるといわれているので，本実験に 用いた鶏卵ではその成分にあまり変化はないと思われ る.すなわち, 卵黄囊内接種の場合においてみられたテ トロドトキシンの鷄胚に対する毒性発現の低下は, 卵黄 の成分あるいは $\mathrm{pH}$ の影響によるものではないかと考兄 る.

しかし気室内接種法では前者に比べていずれも感度は 高く 5 日令に㨟いて最も高い感度を示し, Behrens 法に よって得られたその $\mathrm{LD}_{50}$ 值は $0.044 \mu \mathrm{g} / \mathrm{egg}$ であった. この值はマウス（る，体重 $20 \mathrm{~g}$ ) の腹腔注射による毒性 試験の $\mathrm{LD}_{50}$ 值 $=0.2 \mu \mathrm{g} / \mathrm{mouse}^{8)}$ の約 $1 / 5$ に相当し感度 の高いことが分かった.

気室内接種に掂いて $3,4,5$ 日令と肧令が進む従 って毒性に対する感度が高まり，5日令を最高とし，そ れ以後は漸次低下するといら極めて特徵ある現象がみら れたが，これは血管の発育状態による試料の吸収の難 易, さらには胚の発達による抵抗性の発現によるもので はないかと推測される。

以上の実験結果から, 適当な胈令つまり 5 日令の鷄胚
を用いた気室内接種法によるならば，従来のマウスを用 いた毒力検定法よりも高感度でテトロドトキシンの毒力 の強さを判定することが可能であることが分かった．ま たテトロドトキシンの接種量と䳕胚の致死率との間に, きれいな直線関係のあることを認めた。

な特細部にわたって検討の余地はあるが，供試生物で ある有精鷄卵の入手が容易であること, 実験手技が簡単 であること，また試験を反覆して実施した場合にも，そ の結果の再現性が優れていることなどを考慮すると，フ グ毒の試験法としてこの鶏胚法を応用し得る可能性が高 いと考える.

文献

1) Platt, B.S., Stewart, R.J.C., Gupta, S.R.: Proc. Nutr. Soc. (Engl. Scot.), 21, XXX (1962).

2) Verrett, M. J., Marliac, J.P., McLaughlin, J. Jr.: J. Assoc. Offic. Anal. Chem., 47, 1003 (1964).

3) Adekunle, A. A., Bassir, O.: Toxicol. Appl. Pharmacol., 31, 384 (1975).

4) McLaughlin, J. Jr., Marliac, J.P., Verrett, M. J., Mutchler, M. K., Fitzhugh, O. G.: Amer. Ind. Hyg. Assoc. J., 25, 282 (1964).

5) Gebhardt, D. O. E., Van Logten, M. J.: Toxicol. Appl. Pharmacol., 13, 316 (1968).

6) Sauter, E. A., Steele, E.E.: Poultry Sci., 51, 71 (1971).

7）三浦利之，土田雅子，宮木高明：油化学， 20, 335 (1971).

8) 津田恭介, 河村正明: 薬誌. 72, 187, 771 (1952).

9）小倉保己： 綜合臨床，16，749 (1967).

10）小倉保己：千葉大腐研報，21，1 (1968). 